\title{
Oxidative Stress-Inducing Carbonyl Compounds From Common Foods: Novel Mediators of Cellular Dysfunction
}

\author{
Weijing Cai, Qiao-di Gao, Li Zhu, Melpomeni Peppa, Cijiang He and Helen Vlassara \\ Division of Experimental Diabetes and Aging, Department of Geriatrics, Mount Sinai School of Medicine, \\ New York, NY, USA \\ Accepted June 6, 2002
}

\begin{abstract}
Background: The general increase in reactive oxygen species generated from glucose-derived advanced glycation endproducts (AGEs) is among the key mechanisms implicated in tissue injury due to diabetes. AGE-rich foods could exacerbate diabetic injury, at least by raising the endogenous AGE.

Materials and Methods: Herein, we tested whether, prior to ingestion, diet-derived AGEs contain species with cell activating (TNF $\alpha)$, chemical (cross-linking) or cell oxidative properties, similar to native AGEs. Glutathione (GSH) and GSH peroxidase (GPx) were assessed after exposure of human umbilical vein endothelial cell (HUVECs) to affinity-purified food-AGE extracts, each exposed to $250^{\circ} \mathrm{C}$, for 10 min, along with synthetic AGEs.

Results: Animal product-derived AGE, like synthetic methylglyoxal-bovine serum albumin (MG-BSA), AGE-
\end{abstract}

BSA, and AGE-low density lipoprotein (AGE-LDL), induced a dose- and time-dependent depletion of GSH $(\downarrow 60-75 \%, p<0.01)$ and an increase in GPx activity ( $5500-600 \%, p<0.01)$, consistent with marked TNF $\alpha$ and cross-link formation $(p<0.05)$; this contrasted with the low bioreactivity of starch/vegetable AGE-extracts, which was similar to that of control BSA and CMLBSA and BSA (p:NS). Anti-AGE-R1,2,3 and -RAGE IgG each inhibited cell-associated ${ }^{125}$ I-dAGE by $~ 30-55 \%$; GSH/GPx were effectively blocked by $\mathrm{N}$-acetyl-cysteine (NAC, $800 \mathrm{uM}, \mathrm{p}<0.01$ ) and aminoguanidine-HCl (AG, lo0uM, p $<0.01$ ).

Conclusion: Thus, food-derived AGE, prior to absorption, contain potent carbonyl species, that can induce oxidative stress and promote inflammatory signals.

\section{Introduction}

Chronic accumulation of Advanced Glycation Endoproducts (AGEs) occurs during aging, hyperlipidemia, renal disease, but is especially accelerated in the course of diabetes (1). Reactive dicarbonylprecursors and end products of glycation, also referred to as glycotoxins, in addition to causing inter- and intra-molecular cross-linking, form active intermediates and reactive oxygen species (ROS) $(2,3)$, promoting transcriptional factor NF- $\kappa$ B activation and gene upregulation (4-6). AGEs are generated from multiple sources and mechanisms in vivo, including metal-catalyzed glucose-autoxidation, ascorbate, nitrotyrosine carbonyls and other carbohydrates (7-9). The term AGE, while often referring to non-reactive terminal products, such as ${ }^{\varepsilon} \mathrm{N}$ carboxymethyllysine (CML), pentosidine and other, also includes reactive precursors, such as l-DG, or 3DG and methylglyoxal (MG) (8-11). The latter form by nonoxidative mechanisms from triose phosphate intermediates during anaerobic glycolysis and are found elevated in diabetes $(11,12)$. Lipids are powerful sources of lipid peroxidation products, such as 4-hydroxy-nonenal (HNE), but also of glycoxidation

Address correspondence and reprint requests to: Helen Vlassara, Mount Sinai School of Medicine, Box 1640, New York, NY, 10029, Phone: (212) 659-1551; fax: (212) 849-2652; e-mail: helen.vlassara@mssm.edu. ones, such as CML and their analogues $(13,14)$. Thus, both glycoxidation and lipoxidation products can form on proteins and lipids in vivo $(13,14)$ and together can increase levels of oxidative or carbonyl stress, a term used to encompass both oxidative and non-oxidative reactions $(9,14,15)$. Excessive production or reduced detoxification of these mediators over time can contribute to, while inhibition can prevent, tissue injury related to diabetes or aging $(15,16)$. One pathway for AGE removal involves cellular AGE-specific receptors; components of this system however are also involved in cellular oxidative stress induction and thus, tissue injury $(3,17)$.

AGEs are long known to form in foods during heating (18-20). Some of the AGEs forming in vivo were originally identified in foods, eg., MG, CML, pyrroles and pyridines, while a majority of unstable products remains undefined $(18,19)$. Aside of the modest reduction in the nutritional value or rates of absorption, no major deleterious effects were identified with life-long ingestion of food AGE. Recent reports have confirmed oral absorption (at 10\%), tissue incorporation and renal excretion of end products originating from mixed foods $(20,21)$. The nature of most derivative(s) involved in this traffic has not been determined. However, evidence in support of a role for food-derived AGEs in tissue pathology has begun to emerge: when fed a diet high in glycotoxins, diabetic and non-diabetic 
animals develop more severe vascular (22) or renal tissue injury (23) compared to cohorts fed low glycotoxin diets. Similarly, in models of spontaneous diabetes, disease progression was markedly delayed when fed low-AGE chow (24). Also, in diabetic subjects, placed on low-AGE diet there was a significant reduction of circulating inflammatory markers (25). Thus reactive carbonyl compounds in the diet may act to enhance cellular stress mechanisms under certain conditions such as diabetes. Herein, we sought to determine some of the chemical and cellactivating properties of AGEs in common foods prior to consumption. One of the two AGE indicators monitored in the present studies was CML, a major oxidation end-product of both glyco- and lipoxidation reactions $(13,14)$; the other was MGmodified protein: $M G$ is a highly reactive precursor of AGE, derived from amine-catalyzed sugar fragmentation reactions $(10,11)$. Both products are common in vivo and in foods, are recognized by antibodies raised against AGE-proteins, and used in the detection of glycoxidants in vivo $(26,27)$. We chose cellular GSH/GPx as a cellular anti-oxidant system marker with a dual function; it acts as an antioxidant coenzyme, when used by GSH peroxidase (GPx) to reduce superoxide and yield oxidized glutathione (GSSG); it also acts in a separate capacity in the glyoxalase pathway, facilitating the transformation of MG to D-lactate, thus serving as a major detoxification pathway for dicarbonyls $(28,29)$.

In this study, we have determined that pre-made AGE-contained in common foods can influence cellular homeostasis via intracellular oxidative pathways.

\section{Materials and Methods}

Preparation of Food-derived and Standard AGEs

Food-AGE were selected from among 200 items, and included animal-derived samples, eg., fish, poultry, beef (lean skeletal muscle) or vegetables and starches, eg., pasta or bread. All samples were prepared under identical conditions (heated at $250^{\circ} \mathrm{C}$ for 10 minutes). Following routine homogenization and enzymatic digestion, food mixtures were passed through a lysozyme-Sepharose-B AGE-affinity-chromatography column, as previously described, to remove non-AGE components (30). The bound components were eluted with $0.1 \%$ $\mathrm{NaOH}$, immediately neutralized by $6 \mathrm{M} \mathrm{HCL}$ and stored at $-80^{\circ} \mathrm{C}$, together with un-bound fractions.

Standard AGE-BSA was prepared by incubating bovine serum albumin (BSA) with $0.5 \mathrm{M}$ D-glucose in $0.2 \mathrm{M}$ phosphate buffer ( $\mathrm{pH} 7.4)$ at $37^{\circ} \mathrm{C}$ for $6 \mathrm{wk}$ under sterile conditions $(4,5,30)$. Native albumin was incubated under the same conditions without D-glucose. Methylglyoxal (MG)-BSA (containing 22 MG-modified arginine residues/mol, based on HPLC), MG-ovalbumin (19.2 MG-Arg/mol OA), and ${ }^{\varepsilon} \mathrm{N}$-carboxymethyllysine (CML)-BSA (containing
23 CML-modified lysine residues/mol) were obtained from the laboratory of Dr.Y.Al-Abed (The Picower Institute for Medical Research, Manhasset, NY). Human low-density lipoprotein (LDL) $(d=$ 1.019 to $1.063 \mathrm{~g} / \mathrm{ml}$ ) was separated from normal human plasma by preparative ultracentrifugation and stored in $1 \mathrm{mM}$ EDTA and $100 \mathrm{uM}$ BHT at $4^{\circ} \mathrm{C}$ $(12,13,31)$. Oxidized LDL (Ox-LDL) was generated by incubation of native-LDL $(0.25 \mathrm{mg} / \mathrm{ml})$ with $5 \mu \mathrm{M}$ $\mathrm{CuSO}_{4}$ at $37^{\circ} \mathrm{C}$ for $24 \mathrm{~h} \mathrm{(31).} \mathrm{Based} \mathrm{on} \mathrm{assessment} \mathrm{of}$ thiobarbituric acid-reactive substances (TBARS) (31), oxidized LDL contained 18 malondialdehyde (MDA) $\mathrm{nmol} / \mathrm{mg} \mathrm{LDL}$, compared to $0.1 \mathrm{nmol} / \mathrm{mg}$ in native LDL. To prepare AGE-modified LDL, native LDL $(2 \mathrm{mg} / \mathrm{ml})$ was incubated in PBS containing $0.01 \%$ EDTA, BHT (100 mM) and $0.2 \mathrm{M}$ glucose at $37^{\circ} \mathrm{C}$ for 14 days, then dialyzed against PBS (31). AGE-LDL contained $518 \mathrm{U}$ AGE/mg protein (by $4 \mathrm{G} 9 \mathrm{mab}$ ) and 3.5 MDA nmol/mg.

All sample preparations were passed through an endotoxin-binding affinity column (Pierce, Rockford, IL) to remove endotoxin (tested, by the Limulus amebocyte Lysate, Bio Whittaker, Walkerville, MD).

AGE-immunoreactivity in all samples in this study was largely based on a competitive ELISA, using anti-AGE-KLH monoclonal antibody (4G9 mab) (Alteon, Inc., NJ), previously shown to react strongly with standard CML-modified BSA and AGE-BSA (32-35); in our hands, 4G9 recognized only weakly methyl-glyoxal (MG)-modified BSA, but not BSA or human serum albumin (HSA).

\section{Preparation of Monoclonal Anti-MG-protein Antibody}

As per standard methods, female BALB/c mice were immunized three times with MG-modified ovalbumin (OA) (26). Mouse spleen cells were fused with murine myeloma cells and cultured in hypoxantine/ aminopterin/thymidine (HAT) selection medium. Hybridomas were screened by comparing the reactivities of the culture supernatant to MG-BSA, native BSA, and (OA), as antigens (250 ng /well). Hybridoma cells corresponding to supernatants that were positive for MG-BSA and negative for native BSA or (OA) were cloned by limiting dilution. Two clones, 1A10 and 3D11 with equivalent reactivities for MG-BSA were selected; only $3 \mathrm{D} 11$ is presented here.

To characterize the MG3D11 antibody, serial dilutions of competitor antigens MG-BSA, AGE-BSA, CML-BSA, OA, and BSA ( $1 \mathrm{ng} / \mathrm{ml}-100 \mathrm{ug} / \mathrm{ml})$, as well as MG3D 11 antiserum (titer 1:400) were added sequentially to wells coated with MG-BSA solution (100 ul/well, $10 \mathrm{ng}$ of protein). The plates were incubated at $37^{\circ} \mathrm{C}$ for $2 \mathrm{~h}$. After a series of washes with PBS-Tween and blocking solution, alkaline phosphatase- conjugated rabbit anti-mouse IgG (1:2000) (ICN Biomedicals, Inc. Aurora, $\mathrm{OH}$ ) was added for $\mathrm{l} \mathrm{h}$ at $37^{\circ} \mathrm{C}$, and after a 30-min incubation with pnitrophenyl phosphate (pNPP) at room temperature, absorbance was measured at $405 \mathrm{~nm}$. For quantitation of MG a competitive ELISA was performed. 
A.

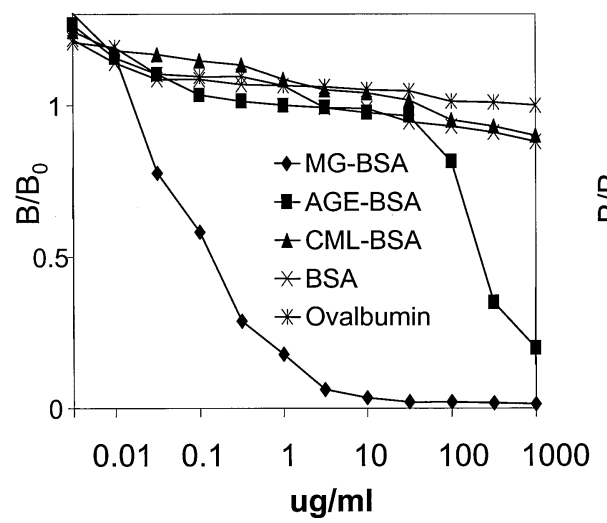

B.

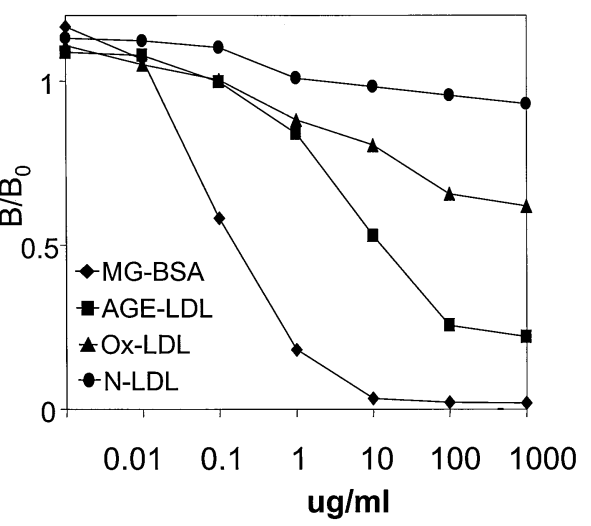

Fig. 1. Binding inhibition curves of anti-MG derivative (MG3D11). Affinity of mouse monoclonal antibody (MG3DII) was determined by a competitive ELISA, as described in methods. Competitive inhibition of antibody binding by modified and unmodified proteins (panel A) or lipid-rich lipoprotein preparations (panel B).
MG 3D11 antibody binding to MG-BSA or AGEBSA-coated plates was competed off by model AGE preparations (Fig. 1A, B). Using this ELISA, MG 3D 11 was found to be highly reactive with MG-BSA (at $0.5 \mathrm{ug} / \mathrm{ml}$ ), with AGE-BSA (at $~ 500 \mathrm{ug} / \mathrm{ml}$ ) and
AGE-LDL (at $100 \mathrm{ug} / \mathrm{ml}$ ), but not with CML-BSA, native-LDL, Oxidized-LDL, BSA or ovalbumin.

MG-immunoreactivity in food extracts was also assessed in food extracts by MG 3D 11 mab (Table 1); data were expressed as $\mathrm{nmol} / \mathrm{ml}$ or per mg protein.

Table 1. Characteristics of selected food AGE extracts ${ }^{\ddagger}$ and AGE standards

A 1.

\begin{tabular}{lccc}
\hline Food Extracts & \multicolumn{2}{c}{ AGE-Immunoreactivity } & TBARS \\
\hline & $\begin{array}{c}\text { Anti-AGE Mab* } \\
(\mathrm{U} / \mathrm{mg})\end{array}$ & $\begin{array}{c}\text { Anti-MG Mab** } \\
(\mathrm{nmol} / \mathrm{mg})\end{array}$ & $\begin{array}{c}\text { MDA }^{\#} \\
(\mathrm{nmol} / \mathrm{mg}\end{array}$ \\
Beef & $582 \pm 32$ & $3.3 \pm 1.0$ & $4 \pm 0.8$ \\
Poultry & $587 \pm 27$ & $3.1 \pm 0.9$ & $7 \pm 1.2$ \\
Fish & $590 \pm 50$ & $3.0 \pm 0.7$ & $2 \pm 0.6$ \\
Pasta & $20 \pm 5$ & $0.9 \pm 0.2$ & 0 \\
Vegetable & $18.7 \pm 7$ & $0.8 \pm 0.3$ & 0 \\
(Cucumber & & &
\end{tabular}

(Cucumber)

B 1.

\section{Model AGE}

\section{AGE-Immunoreactivity}

\begin{tabular}{lcc}
\hline & $\begin{array}{c}\text { Anti-AGE Mab* } \\
(\mathrm{U} / \mathrm{mg})\end{array}$ & $\begin{array}{c}\text { Anti-MG Mab** } \\
(\mathrm{nmol} / \mathrm{mg})\end{array}$ \\
& $76 \pm 17$ & $0.12 \pm 0.04$ \\
AGE-BSA & $47 \pm 5$ & $5.3 \pm 1.6$ \\
MG-BSA & $109 \pm 18$ & 0 \\
CML-BSA & $1 \pm 0.18$ & 0 \\
BSA &
\end{tabular}

A 2.

\begin{tabular}{lcc}
\hline Food Extracts & \multicolumn{2}{c}{ Bio-Reactivity } \\
\hline$(10 \mathrm{U} / \mathrm{ml})$ & $\begin{array}{c}\text { TNF- } \alpha^{\S} \\
(\mathrm{ng} / \mathrm{mg})\end{array}$ & $\begin{array}{c}\text { Crosslinking } \\
\end{array}$
\end{tabular}

Beef $\quad 7.8 \pm 0.6 \quad 85$

Poultry $\quad 8.1 \pm 0.2 \quad 110$

$\begin{array}{lll}\text { Fish } & 6.0 \pm 0.4 & 9.2\end{array}$

Pasta $\quad 1.4 \pm 0.1 \quad 2.8$

Vegetable $\quad 1.5 \pm 0.3 \quad 2.5$ (Cucumber)

B 2.

\begin{tabular}{lcc}
\hline Model AGE & \multicolumn{2}{c}{ Bio-Reactivity } \\
\hline$(100 \mathrm{ug} / \mathrm{ml})$ & $\begin{array}{c}\text { TNF- } \alpha^{\S} \\
(\mathrm{ng} / \mathrm{mg})\end{array}$ & $\begin{array}{c}\text { Crosslinking }^{\dagger} \\
\text { (HMW formation) } \times \text { fold }^{-}\end{array}$ \\
AGE-BSA & $30.6 \pm 10.6$ & 91 \\
MG-BSA & $43.3 \pm 20$ & 55 \\
CML-BSA & $8.5 \pm 6.1$ & 2 \\
BSA & $1.5 \pm 0.5$ & 1
\end{tabular}

\footnotetext{
"AGE rich food extracts were affinity-purified, as described under "Methods".

*Based on 4G9 (CML-sensitive) Mab.

**Based on MG-3D11 Mab.

${ }^{\text {s }}$ TNF- $\alpha$ were measured by a solid sandwich ELISA kit (BioSource International, Inc. Camarillo, CA) from cell supernatants. Cells (ATCC TIB-186, $1 \times 10^{6} /$ well) were exposed a 10AGE units $/ \mathrm{ml}$ (based on 4G9 Mab) in (A.) and $100 \mathrm{ug}$ of protein $/ \mathrm{ml}$ in (B.), 1 AGEU $(4 \mathrm{G} 9) \approx 10$ ug CML-BSA.

${ }^{\dagger}$ High molecular weight (HMW) complex formation by ${ }^{125}$ I-fibronectin fragments are shown as x-fold increase above native BSA.

${ }^{\#}$ MDA - malondialdehyde.
} 


\section{Bio-reactivity of Food AGE Extracts}

Macrophage for TNF- $\alpha$ Production Mouse peritoneal macrophages (ATCC TIB-186) were exposed to samples of equivalent AGE concentration from food AGE extracts (or model AGE preparations) for $24 \mathrm{~h}$ at $37^{\circ} \mathrm{C}$. TNF- $\alpha$ protein in cell supernatants was measured by a solid sandwich ELISA using commercially available kits (BioSource International, Inc. Camarillo, CA).

Crosslinking Activity The chemical crosslinking assay used has been described in detail previously (30). Briefly, equal amounts (10 AGE units) of affinity purified food extracts, or model AGE $(100 \mathrm{ug} / \mathrm{ml})$ were incubated with ${ }^{125} \mathrm{I}$-labeled fibronectin fragments (Sigma) $\left(1 \times 10^{6} \mathrm{cpm} / \mathrm{sample}\right.$, specific activity, $10 \times 10^{5} \mathrm{cpm} / \mathrm{ng}$ ) at $37^{\circ}$ for $72 \mathrm{~h}$. After gradient SDS gel electrophoresis (4-20\%) and autoradiography, high molecular weight (HMW) complex formation $(>200 \mathrm{kDa})$ in each mixture was quantitated by densitometry.

HUVEC Glutathione (GSH) and Glutathione Peroxidase (GPX) Activity Human umbilical vein endothelial cells (HUVECs) from ATCC were cultured in complete medium with $10 \%$ fetal bovine serum (FBS) at $37^{\circ} \mathrm{C}$ in $95 \%$ air and $5 \% \mathrm{CO}_{2}$. For each experiment, cells were plated into 6-well plates $\left(1 \times 10^{6} /\right.$ well $)$ overnight and serum-restricted for $5 \mathrm{~h}$. After exposure to equal amounts of foodderived affinity-purified samples or standard modified-proteins (AGE-BSA, MG-BSA, CMLBSA) or lipids (ox-LDL and AGE-LDL) for the indicated time intervals, cells were resuspended in ice-cold metaphosphoric acid (MPA) working solution $(5 \%)$, homogenized by sonication and centrifuged (4000 g at $4^{\circ} \mathrm{C}$ for $\left.5 \mathrm{~min}\right) ; 300 \mathrm{ul}$ of each supernatant were used for GSH measurement (OXIS International, Inc. Portland, OR) by colorimetric assay, at $400 \mathrm{~nm}$. For GPx, cells were resuspended in ice-cold TRIS-HCL buffer $(50 \mathrm{mM}$ TRIS-HCL, pH 7.5, containing $5 \mathrm{mM}$ EDTA and $1 \mathrm{mM} \mathrm{2-}$ mercaptoethanol); after centrifugation (4000 $\mathrm{g}$ at $4^{\circ} \mathrm{C}$ for $5 \mathrm{~min}$ ) the supernatants were collected. Using reduced glutathione and hydrogen peroxide as substrates, oxidized glutathione produced by GPx was monitored at an absorbance of $340 \mathrm{~nm}$ (OXIS International, Inc. Portland, OR). Specific activities were expressed as nmol of NADPH $\mathrm{min}^{-1} \mathrm{mg}^{-1}$ protein. The protein content was determined using the Bio-Rad protein assay kit (Bio-Rad Laboratories, Hercules, CA). Also, aliquots from the unbound to the affinity-column fractions were also tested for AGE, TBARS and GSH/GPx activities, at equal protein concentration as standard AGEs. Parallel experiments were also performed in the presence or absence of $\mathrm{N}$ acetylcysteine (NAC, $800 \mathrm{uM}$ ) or Aminoguanidine (AG, $100 \mathrm{uM}$ ).
Cell-associated Radioactive Assay

Aliquots from an affinity-purified AGE-rich food extract (bovine muscle) or AGE-standards (AGEBSA, AGE-LDL) were ${ }^{125}$ I-labeled by the IODObead method (Pierce, Rockford, IL), as per manufacturer's instructions (specific radioactivities ranged at 552-718 cpm/ng). HUVECs $\left(5 \times 10^{5} /\right.$ well $)$ were maintained in serum-free medium for $5 \mathrm{~h}$ at $37^{\circ} \mathrm{C}$ and then incubated with each labeled preparation $(10 \mathrm{ug} / \mathrm{ml})$, with or without 100 -fold excess of unlabeled ligand added to fresh serum-free media. After $2 \mathrm{~h}$ at $37^{\circ} \mathrm{C}$, cells were lysed with $\mathrm{NaOH}(0.5 \mathrm{ml}$, $0.1 \mathrm{~N}$ ) and $20 \mathrm{ul}$ of the cell lysate was used to determine radioactivity. Protein concentration was assayed by Bio-Rad assay. AGE-specific cell associated radioactivity was determined by subtracting nonspecific from total cpm, as described $(4,5)$.

Identical experiments were performed as described above, in the presence of previously characterized anti-AGE-receptor 1-3 $(36,37)$ or anti-RAGE antibodies (the latter obtained as a generous gift from Novartis Pharma Co.) at $50 \mathrm{ug} / \mathrm{ml}$ for $\mathrm{lhr}$ $\left(37^{\circ} \mathrm{C}\right)$. Data were expressed as \% of AGE-specific cpm found in the absence of antibody and are shown as $M \pm$ SEM of three experiments, each in triplicate.

\section{Statistical Analysis}

Values were expressed as the means \pm SD of SEM of multiple experiments as indicated and were assessed by the unpaired Student's $t$ test. Differences between each group were considered as statistically significant at $p<0.05$ or $p<0.01$.

\section{Results}

Characterization of Mouse Monoclonal Antibody Against Protein Derivatives of $M G$

The titer in the MG3D1l was estimated at 1:400, in a direct ELISA (not shown), and the antibody's (IgG) specificity was tested by competitive ELISA against several modified and unmodified proteins (Fig. 1A, B). A most pronounced antibody-binding inhibition was observed with BSA modified by MG, followed by BSA modified by glucose (AGE-BSA). MG3D 11 IgG recognized MG-derived epitopes on MG-modified BSA at nanomolar concentrations, but not on CML-BSA. A lower reactivity was observed for AGE-BSA (at $100 \mathrm{ug} / \mathrm{ml}$ ) confirming the presence of MG-derivatives in the mixture of glycoxidation products in this preparation. MG3Dil showed no cross-reactivity for the antigen carrier BSA, nor for the heterologous ovalbumin, which was used as carrier for the immunogen. In addition, MG3D11 cross-reacted with glucose-derived AGE-LDL, but not for non-glucose related Ox-LDL, nor for native LDL (Fig. 1B). To determine whether in vivo MGmodified proteins cross-reacted with MG3D11, human serum samples were tested: a significant difference between normal $(\mathrm{n}=12,0.44 \pm 0.12 \mathrm{nmol} / \mathrm{ml})$ 
and diabetic sera $(\mathrm{n}=15,1.32 \pm 0.4 \mathrm{nmol} / \mathrm{ml})$ was observed $(p<0.01)$. Also, select food extracts and AGE standards tested positive (Table 1). The degree of MG-modification on complex samples could not be accurately assessed by competitive inhibition, as lysine and arginine content (and therefore AGE derivatives) in these samples varied. However, higher levels of MG-derived immunoreactivity coincided with higher CML in the same preparation (Table 1). Antibody cross-reactivity was not observed using solutions containing either glucose, or lysine alone (data not shown). Together these data indicate that MG3DII is essentially specific for MG-modified protein derivatives, possibly imidazolone adducts (9-11,38); while no other early or intermediate AGE were tested in this series, the late MG-derivative, CML tested negative.

\section{Properties of AGE-containing Food Extracts}

Higher CML- and MG-specific immunoreactivities in the group of animal-derived extracts than in vegetable or starch-derivatives (Table 1) were consistent with, and likely due to the presence of variable amounts of fat, a rich source of lipoxidation products. Extracts from animal sources, when compared to low or no fat products yielded generally higher concentrations of CML, an oxidation end-product of both glyco- and lipoxidation reactions (by $\sim 30$ fold). The meat-group extracts also contained significant levels of MG and of MDA, but only $\sim 3$-fold higher than low-fat samples (Table 1A). This could be attributed to the transient/unstable nature of these intermediates, which evolve rapidly to terminal oxidation products, as CML; it also highlights the presence of lipids present in close proximity to glycation derivatives and their importance in the interplay between distinct oxidative pathways. Fractions extracted from animal products, eg., meat, which were not bound by AGE-affinity column exhibited lower AGE (41 U/mg by 4G9, nondetectable MG-derivatives, but considerable levels of oxidation products, MDA: $3.0 \mathrm{nmol} / \mathrm{mg}$ ) compared to bound fractions (582 U/mg AGE and 4-7 nmol/mg MDA).

A similar relationship between glycoxidant content and nutrient composition of food extracts was noted with regard to two known bio-reactivity properties, e.g. macrophage-cytokine $(\mathrm{TNF} \alpha)$ induction and inter-molecular covalent cross-link formation (Table 1B). Although all food samples were applied at equal levels of CML $(\sim 10 \mathrm{U}$, or $\sim 100 \mu \mathrm{g}$ AGE- BSA, by 4G9 ELISA), animal products, which were also rich in lipid oxidation products based on MDA content promoted greater TNF $\alpha$ and proteinprotein crosslink formation than samples low in lipids (Table 1B). Fish-derived extracts, comparable in CML- and MG-derivatives, but clearly lower in total fat and in MDA content than other meat extracts, exhibited lower TNF- $\alpha$, and cross-linking potential possibly due to less oxidizable fatty acid content. Of interest, when synthetic MG-BSA was applied alone, it promoted far greater TNF- $\alpha$ production and HMW aggregate formation than did CML-BSA (Table 1B). This may imply that products related to MG derivatives in foods are more potent mediators of these activities than terminal products, as CML.

\section{Intracellular Oxidative Stress (OS) Is Increased in HUVECS Exposed to Food-derived AGEs (dAGEs)}

To assess whether the cell-activating property of foodAGE extracts involves intracellular oxidant stress (OS) induction, food extracts were tested, at doses within the physiologic range (1-50 AGE U/ml, based on 4G9 mab), in parallel with various standards, applied as a function of protein concentration (Fig. 2, A-D). A dose dependent depletion of GSH was observed, using standard glycated proteins; maximal GSH depletion was induced by MG-derivatives ( $\sim 75 \%$ below baseline), followed by AGE-LDL and Ox-LDL, while CML-BSA, LDL and BSA did not mimic this effect. Similar food-derived AGE-enriched extracts from animal sources prompted significant, AGE-dose dependent GSH decline (by 60-75\% from baseline, $p<0.01$ ) (Fig. 2C). Extracts of non-animal origin (starch/ pasta), tested at similar AGE concentrations were far less effective in altering GSH levels, and similar to BSA and CML-BSA. Fractions of food extracts not bound by the AGE-affinity column, but containing considerable levels of lipid peroxidation products (MDA $3 \mathrm{nmol} / \mathrm{mg}$ ) induced only modest GSH depletion (by $30 \%)$ at equal $(100 \mathrm{ug} / \mathrm{ml})$ protein concentrations (data not shown).

Consistent with the above data, glutathione peroxidase (GPx) activity in HUVEC increased maximally in response to MG-BSA, followed by AGE-LDL and Ox-LDL in response to protein dosedependent manner (up to 5-fold above control, $p<$ 0.01) (Fig. 2B). Similarly, significant GPx activity was induced readily by meat-derived AGE and to a much smaller degree by starch AGE (Fig. 2D). Compared to AGE BSA, the required concentration of meat AGE for maximal GPx activity was fivefold lower $(p<0.01)$, pointing again to a possible enhancing effect of glyco- and lipoxidation derivatives in the latter. Here again, un-bound fractions of food extracts induced only modest GPx activity by 1.5-fold above CL (data not shown).

Time-dependent changes in GSH/GPx are shown in Fig. 3, A-B. Maximal reductions in GSH occurred between 2 and $4 \mathrm{~h}$ incubation of HUVEC with dAGE, and remained low for up to $8 \mathrm{~h}$; corresponding changes in GPx peaked at $2 \mathrm{~h}$ and subsided within 4 hrs uniformly.

Effects of N-acetylcysteine (NAC) and Aminoguanidine- $\mathrm{HCl}$ $(A G)$ on Cellular Oxidative Stress (OS) Induced by Food-derived $A G E$

The addition of either $\mathrm{N}$-acetyl-cysteine (NAC, $800 \mathrm{uM})$ or aminoguanidine- $\mathrm{HCl}(\mathrm{AG}, 100 \mathrm{uM})$ to 


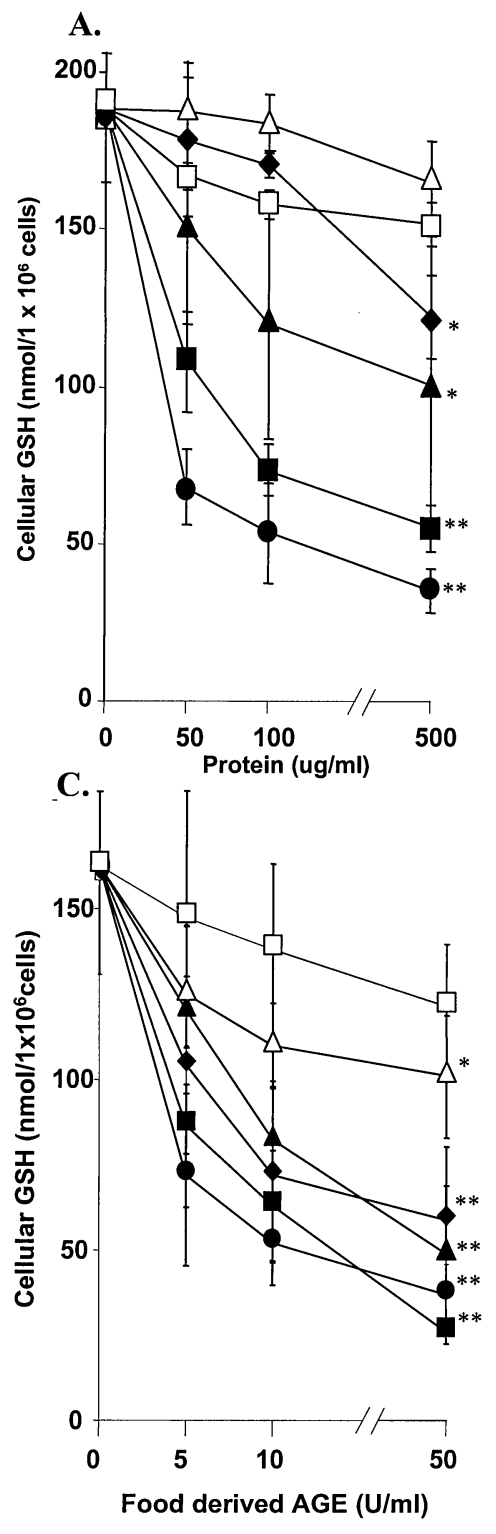

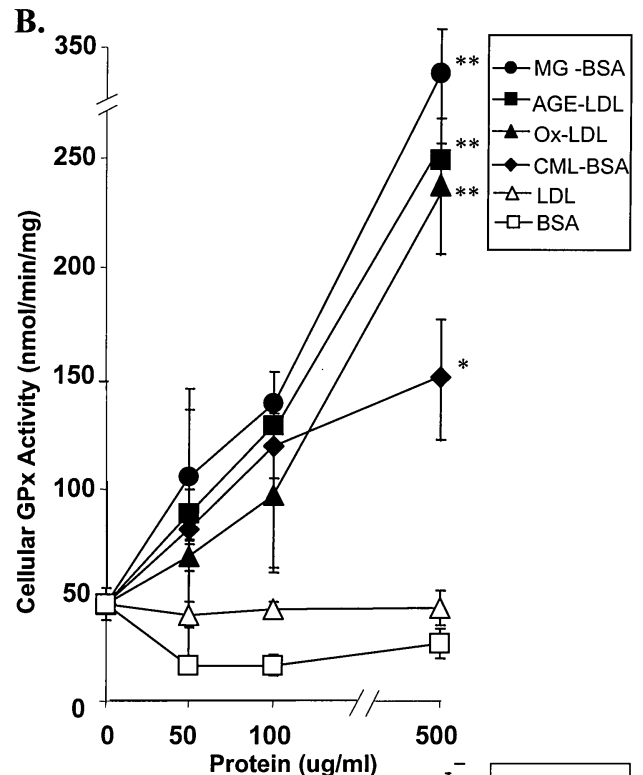

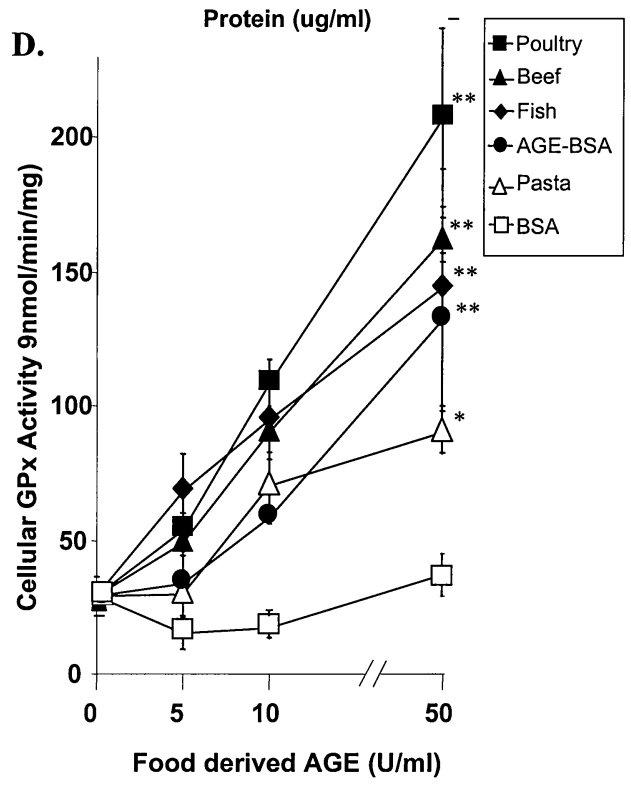

Fig. 2. Food-derived AGE promote cellular glutathione (GSH) depletion and glutathione peroxidase (GPx) activation: Dose response. HUVECs $\left(1 \times 10^{6}\right.$ cells/well $)$, after serum restriction $\times 5 \mathrm{~h}$, were incubated with the indicated amounts of standards protein (A, B) or extracts from foods samples prepared identically at $250^{\circ}, 10 \mathrm{~min}$ for $2 \mathrm{~h}$ (C, D) and enriched for AGE after passage through an affinity column, as described. Values represent mean \pm SD of three independent experiments. $\left({ }^{*} p<0.05\right.$. ${ }^{* *} p<0.01 v s$ control media) cells exposed to optimal amounts $(50 \mathrm{U} / \mathrm{ml})$ of foodAGE extracts, or standard AGE obliterated effectively GSH depletion and GPx activation (Fig. 4, A-B). Here again, CML proved a much less potent OS promoter compared to MG-, AGE-BSA or foodderived AGE. Accordingly, the sparing effects of NAC and AG were less marked in cells exposed to CML-BSA.

\section{Interaction of Food-derived AGE with HUVECs;} Contribution of Cell Surface AGE-Receptors

To test whether food-derived AGE (dAGE) intracellular OS involved cellular AGE-receptors (AGE-R ${ }_{1}$, AGE-R ${ }_{2}$ AGE-R ${ }_{3}$ or RAGE), ${ }^{125}$ I-dAGE-specific cell-associated radioactivity was assessed along with standard labeled AGE-BSA and AGE-LDL (Fig. 5, A-C). Total HUVEC-associated ${ }^{125}$ I-diet-AGE (10 ug/ml, affinity-purified bovine muscle extract) was effectively inhibited by an excess amount of unlabeled dAGE (by $>60 \%$ ), indicating that a significant portion of the bound substances engage cellular-receptor sites; cross-competition studies, using dAGE against ${ }^{125}$ I-AGE-BSA or AGE-LDL were even more effective (by $75 \%$ ), confirming that dAGE, as tested herein, interacted via AGEreceptors (Fig. 5A). The participation of known AGE-specific receptors in this interaction was probed further, using anti-AGE-receptor antibodies, under identical conditions (Fig. 5, B-C). At optimal antibody concentrations $(50 \mathrm{ug} / \mathrm{ml})$, cell-associated ${ }^{125}$ I-dAGE was inhibited to a substantial, though partial degree (anti-R1, -2 , or -3 : by $\sim 50-55 \%$, and anti-RAGE: by $30 \%$ ); similar antibody-inhibition was noted against the control ligand ${ }^{125} \mathrm{I}-\mathrm{AGE}-\mathrm{BSA}$ (by $\alpha$-R1: $\sim 60 \%$, by $\alpha-\mathrm{R} 2: \sim 50 \%$, by $\alpha-\mathrm{R} 3: \sim 70 \%$ and by $\alpha$-RAGE: $\sim 75 \%, p<0.05$ or $p<0.01$, 


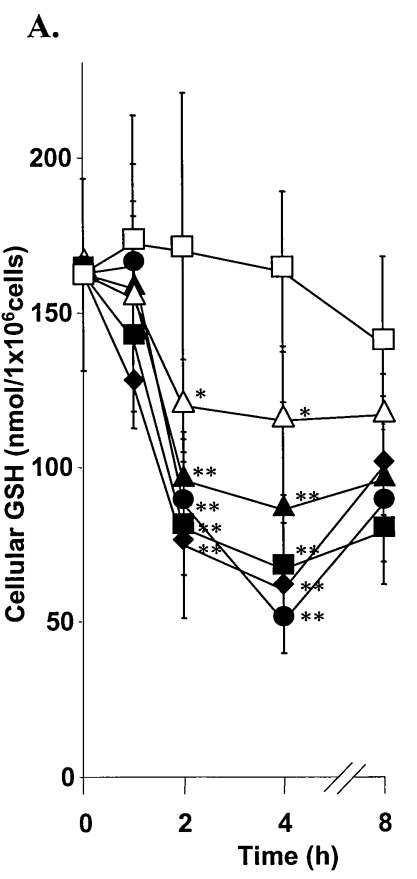

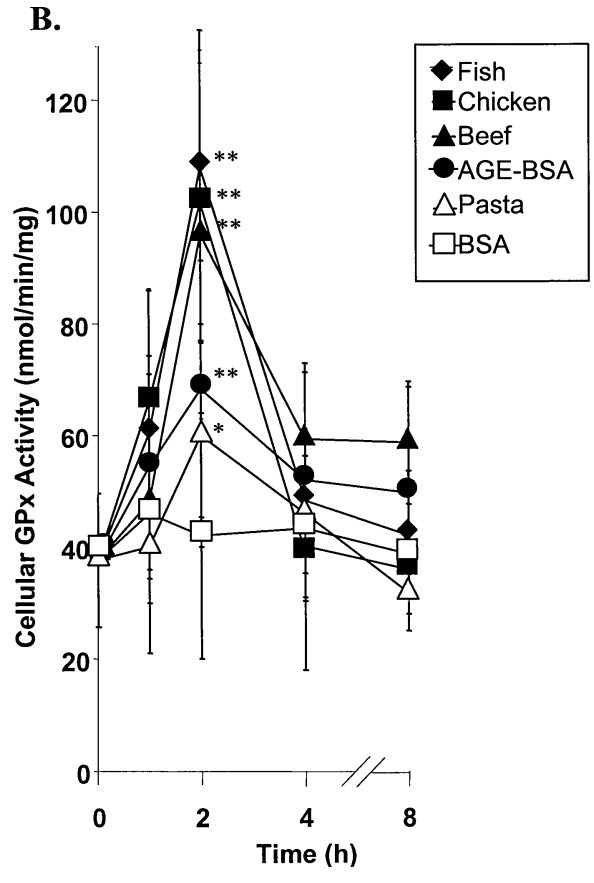

Fig. 3. Time course of cellular GSH depletion (A) and GPx activation (B) by dietary AGE. HUVECs $\left(1 \times 10^{6}\right.$ cells/well $)$ were incubated with equal amount of dietary AGE-extracts ( $10 \mathrm{U} / \mathrm{ml}$, by on $4 \mathrm{G} 9 \mathrm{mab})$ prepared as in Fig. 2., for the indicated times. Values represent mean \pm SD of three independent experiments. $\left({ }^{*} p<0.05\right.$. ${ }^{* *} p<$ 0.01 vs BSA) respectively). These data indicated that these AGEreceptors, while important, are not the sole mediators of the effects elicited by dAGE mixtures.

\section{Discussion}

The present report provides evidence that common foods, as used for human consumption contain protein, and lipid glycoxidation products which can target directly key cellular anti-oxidant defense systems. The evidence confirms and provides a new mechanistic basis for the association between tissue pathology and AGE-rich diets and the prevention thereof by diets low in AGE (22-25).

Increasing evidence supports the role of ROS and intracellular OS in the pathogenesis of diabetes and diabetic complications, via intersecting pathways, one of which is fueled by glucose-driven extra- and intracellular AGE and their carbonyl precursors $(9,14,39)$. Recent studies have indicated that
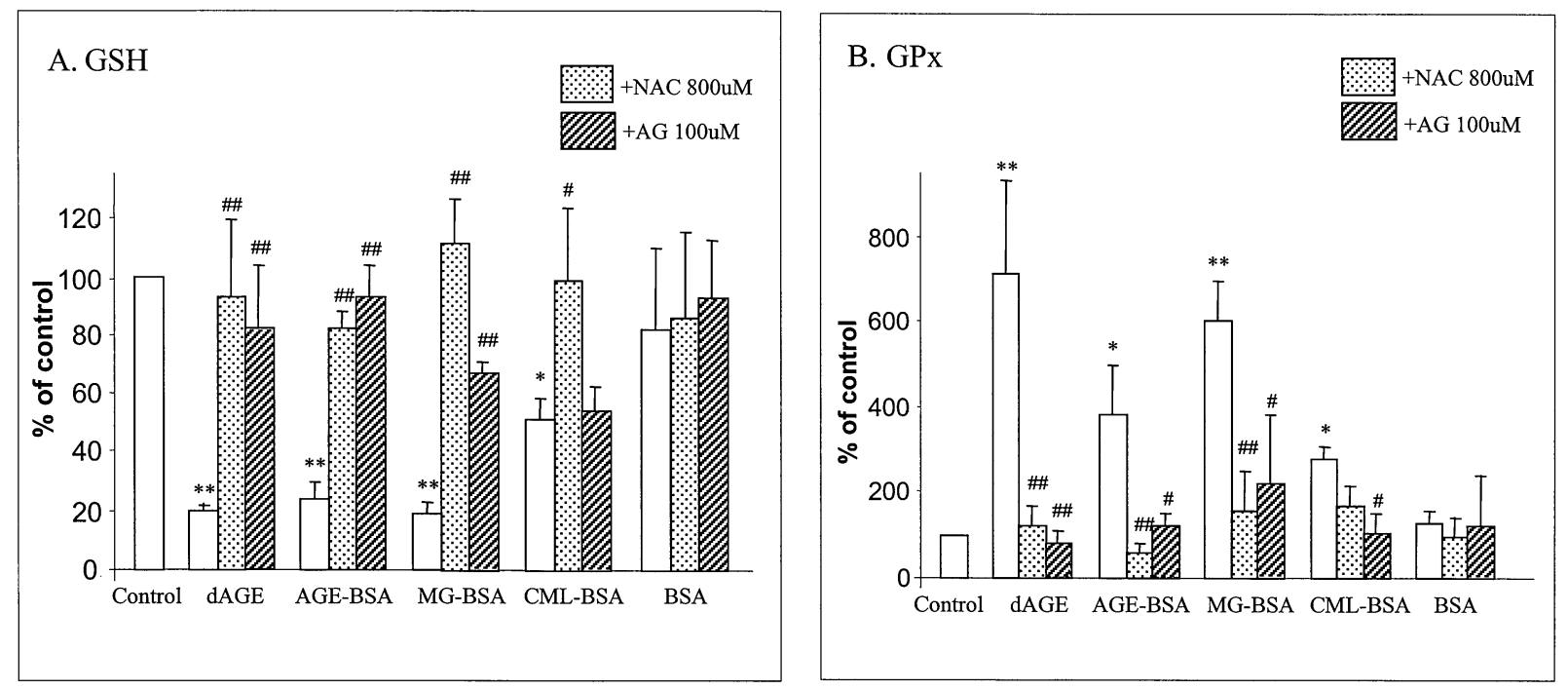

Fig. 4. Effect of N-acetylcysteine (NAC) and aminoguanidine-HCL (AG) on dietary AGE-induced GSH depletion (A) and GPx activation (B). HUVECs $\left(1 \times 10^{6}\right.$ cells/well $)$ were incubated with NAC $(800 \mathrm{uM})$ or AG $(100 \mathrm{uM})$ and the indicated AGE standards (max. $500 \mathrm{ug} / \mathrm{ml}$ ) or dietary AGE-extracts, prepared as described in Fig. 2., (50 U/ml by $4 \mathrm{G} 9$ ) for $2 \mathrm{~h}$ at $37^{\circ} \mathrm{C}$. Cellular GSH and GPx were determined as described in methods. Data are expressed as mean \pm SD of three independent experiments. $\left({ }^{*} p<0.05\right.$ or ${ }^{* *} p<0.01$ vs control media; ${ }^{\#} p<0.05$ or ${ }^{\# \#} p<0.01$ vs no NAC or AG added) 

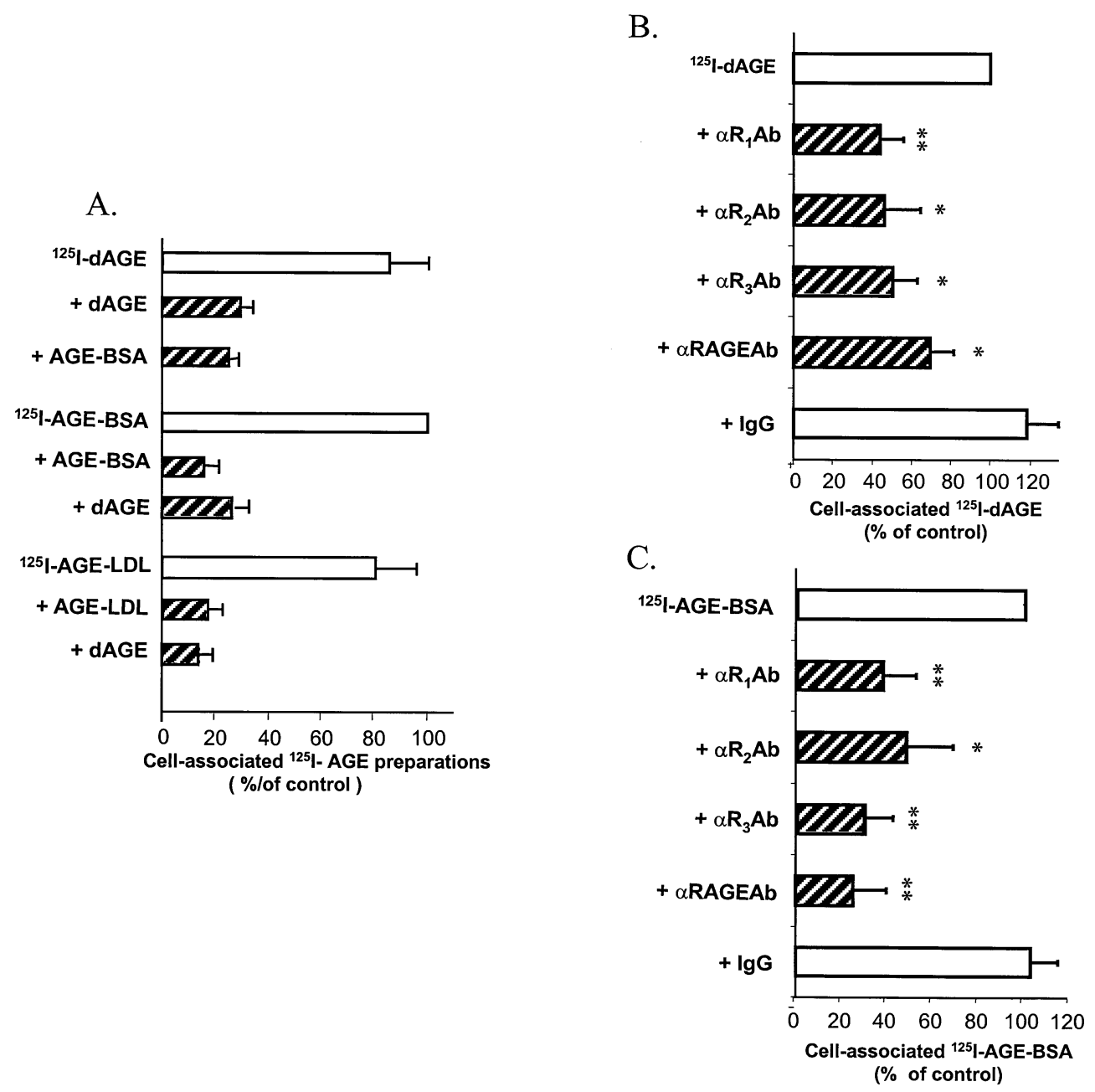

Fig. 5. Cellular interactions of ${ }^{125}$ I-dietary AGE are in part AGE-receptor dependent Panel A: HUVECs $\left(1 \times 10^{6}\right.$ cells/well) were incubated with $10 \mathrm{ug} / \mathrm{ml}$ of ${ }^{125} \mathrm{I}$-dAGEs (AGE-affinity purified extract from bovine muscle, $250^{\circ}, 10 \mathrm{~min}$ ) or ${ }^{125} \mathrm{I}$ - AGE-BSA or ${ }^{125} \mathrm{I}-\mathrm{AGE}-\mathrm{LDL}$ in the presence or absence of 100 -fold excess of each unlabeled ligand for $2 \mathrm{~h}$, at $37^{\circ} \mathrm{C}$. Results are expressed as cell associated cpm (mean \pm SD) of three independent experiments, each performed in triplicate. Panels B and C: Effect of anti-AGEreceptor 1, 2, 3 or RAGE antibodies on cell associated ${ }^{125} \mathrm{I}$ - food-extract prepared as described in A (Panel B) or standard AGE (Panel C). Antibodies or nonimmune rabbit IgG $(50 \mathrm{ug} / \mathrm{ml})$ were added to HUVECs for $1 \mathrm{~h}$ at $37^{\circ} \mathrm{C}$, before of ${ }^{125} \mathrm{I}$ labeled ligands $(10 \mathrm{ug} / \mathrm{ml})$ were applied for $2 \mathrm{~h}$, at $37^{\circ} \mathrm{C}$. Cell-associated cpm were determined after correcting for nonspecific binding as described. After the addition of each antibody data were expressed as \% of cpm bound in the absence of antibody. Results are shown as mean $\pm \mathrm{SD}$ of three independent experiments, each performed in triplicate. $\left({ }^{*} p<0.05 .{ }^{* *} p<0.01\right)$

a significant amount of such reactive compounds is absorbed with foods, enlarging the pool of endogenous glycoxidants that may already stress native defense systems, especially in diabetes with its complex carbohydrate and lipid-related imbalances.

In the present report we demonstrate that carbonyl-rich foods, collectively carry significant chemical and cell-activating (TNF $\alpha$ generating) properties, even prior to being ingested. These correlate with AGE content and resembled those of native AGE and are consistent with nutrient composition as reported (18-21). The earlier findings, however, while supportive, did not determine whether food AGE constitute an independent source of "pathogens," distinct from those endogenously generated. Based on the finding, as this is now established, identically prepared food extracts, tested at the pre-ingestion stage, are capable of triggering injurious processes.

Among the numerous cellular anti-oxidant systems, GSH/GPx was selected for testing intracellular oxidative status in endothelial cells. As mentioned, GSH is a coenzyme, which has discrete antioxidant as well as detoxification activities $(9,28,29)$ and provided a means for assessing dAGE-induced OS, irrespective of whether these derived from peroxides or carbonyl intermediates.

In these studies GSH was significantly compromised by substances contained in foods in a dose- and time-dependent manner. The effect was due largely to AGE, as it was elicited maximally by AGE-rich, and not by AGE-depleted fractions. Although most food samples comprised a mixture of substances, certain 
parallels could be drawn between them and the synthetic MG-modified protein, but not with CMLprotein, although both are shown to induce oxidant stress $(3,39,40)$. GSH was depleted more effectively by MG-, than by CML-modified proteins. The same pattern was noted with regard to TNF $\alpha$ or crosslink formation. The disparity found between these two common AGE compounds could be due to the methods applied. However, several pieces of evidence suggest that MG precursors or derivatives may be among the key food AGE classes responsible for cellular OS: The major MG-derivative monitored herein are likely to represent arg-imidazolone, based on the high MG-arginine content of the immunogen used to develop monoclonal antibodies; however, the presence of imidazolium crosslinks, such as lysine-MG dimers (MOLD) or other dicarbonyl compounds, shown to exert similar effects, cannot be excluded (41). Other MG-precursors can induce oxidative stress and apoptosis in cells $(39,40,42$,) and their presence in the tested food samples cannot be ruled out either. Another pathway by which foodcontained MG can contribute to increased intracellular OS is via food-MG modification and inactivation of enzymes, which scavenge ROS, such as superoxide dismutase, glutathione peroxidase, and glutathione transferase $(39,40)$.

In this study, dAGE samples were isolated from different animal sources, fish, poultry, and beef. These sources are rich in both glycoxidation and lipoxidation derivatives. Phospholipids with free amines are abundant in animal products and can engage in complex, mutually enhancing glyco-, and lipoxidation reactions $(14,43)$.

Cellular responses to AGE, including endocytosis and removal, as well as increased OS, signaling and NF-KB activation have all been linked to specific receptors, such as RAGE, AGE-R1, AGE-R2, and AGE-R3, and scavenger receptors $(6,36,44-46)$. The findings presented suggest that most of these are shared with exogenous AGE, while other pathways are likely involved. Specific inferences from antibody inhibition studies are difficult to make. If confirmed, these data could help re-define the existing framework of AGE-receptor-based detoxification mechanisms. It is thus possible that exogenous AGE lead to sustained saturation of this receptor system or altered receptor gene expression. This possibility may explain the difficulties encountered with functional receptor studies in vivo.

Irrespective of mode of cell entry, intracellular oxidative stress caused by dAGE rich preparations is reversible by known inhibitors, NAC and AG. A known inhibitor of AGE formation, AG is also a carbonyl scavenger, preventing lipid peroxidation and ROS formation $(47,48)$. NAC reduces free radical species and other oxidants (49) and increases levels of glutathione effectively (50). The fact that GSH depletion by food AGE was prevented by both AG and NAC strengthens the supposition that dietary AGE mixtures include species descending from both, oxidative or non-oxidative reaction pathways.

In conclusion, the study shows that food derived glyco- and lipoxidation products are potent promoters of chemical and intracellular oxidative stress. This may be in part facilitated by cell-surface AGEreceptors; overt in vivo saturation of this important clearance mechanism may be cause for greater cellular stress via alternate routes. Together with the in vivo animal (22-25) and clinical studies, the evidence presented provides the basis for placing food AGE in the category of potentially serious environmental risk factors.

Future studies are warranted for the elucidation of food glycoxidant species that are involved in the observed effects.

\section{Acknowledgments}

This work was supported in part by the National Institute of Health grant DK54788 to H.V. and AG09453 to H.V. We thank Ina Katz for invaluable editorial assistance.

\section{References}

1. Brownlee M, Cerami A, Vlassara H. (1988) Advanced glycosylation endproducts in tissue and biochemical basis of diabetic complications. N. Eng. J. Med. 318: 1315-1321.

2. Vincenzo S, Ganz MB, and Weiss MF. (2000) AGEs induce oxidative stress and activate protein kinase C- $\beta_{\mathrm{II}}$ in neonatal mesangial cells. Am. J. Physiol. Renal Physiol. 278: F676-F683.

3. Lander HM, Tauras JM, Ogiste J, et al. (1997) Activation of the receptor for advanced glycation end products triggers a p2 $1^{\text {ras }}$-dependent mitogen-activated protein kinase pathway regulated by oxidant stress. J. Biol. Chem. 272: 17810-17814.

4. Esposito S, Gerlach H, Brett J, et al. (1989) Endothelial receptor-mediated binding of glucose-modified albumin is associated with increased monolayer permerbility and modulation of cell surface coagulant properties. J. Exp. Med. 170: 1387-1407.

5. Schmidt AM, Hori O, Chen J, et al. (1995) Advanced glycation endproducts interacting with their endothelial receptor induce expression of vascular cell adhesion molecule-1 (VCAM-1) in cultured human endothelial cells and in mice. J. Clin. Invest. 96: 1395-1403.

6. Vlassara H, Fuh H, Donnelly T, Cybulaky M. (1995) Advanced glycation endproducts promote adhesion molecule (VCAM-1, ICAM-1) expression and atheroma formation in normal rabbits. Mol. Med. 1(4): 447-456.

7. Hamada Y, Araki N, Koh N, et al. (1996) Rapid formation of advanced glycation end products by intermediate metabolites of glycolytic pathway and polyol pathway. Biochem. Biophys. Res. Commun. 228: 539-543.

8. Hazen SL, Heinecke JW. (1997) 3-Chlorotyrosine: a specific marker of meloperoxidase-catalyzed oxidation, is markedly elevated in low density lipoprotein isolated from human atherosclerotic intima. J. Clin. Invest. 99: 2075-2081.

9. Baynes JW, Thorpe SR. (1999) Role of oxidative stress in diabetic complications, a new perspective on an old paradigm. Diabetes 48: 1-9.

10. Thornalley PJ. (1996) Pharmacology of methylglyoxal. Gen. Pharmacol. 27: 565-573.

11. Thornalley PJ, Hoop NI, Jennings PE, et al. (1989) The human red blood glyoxalas system in diabetes mellitus. Diabetes Res. Clin. Pract. 7: 115-120.

12. Bucala R, Makita Z, Koschinsky T, et al. (1993) Lipid advanced glycosylation: pathway for lipid oxidation in vivo. Proc. Natl. Acad. Sci. USA 90: 6634-6638. 
13. Requena JR, Ahmed MU, Fountain CW, et al. (1997) Carboxymethylethanolamine: a biomarker of phospholipid modification during the maillard reaction in vivo. J. Biol. Chem. 272: 17473-17479.

14. Fu MX, Requena JR, Jenkins AJ, et al. (1996) The advanced glycation end product, $\mathrm{N}^{\varepsilon}$-(Carboxymethyl)lysine, is a product of both lipid peroxidation and glycoxidation reactions. J. Biol. Chem. 271: 9982-9986.

15. Thorpe SR, Baynes JW. (1996) Role of the maillard reaction in diabetes mellitus and diseases of aging. Drugs Aging. 9: 69-77.

16. Li YM, Steffes M, Donnelly T, et al. (1996) Prevention of cardiovascular and renal pathology of aging by the advanced glycation inhibitor aminoguanidine. Proc. Natl. Acad. Sci. USA 93: 3902-3907.

17. Vlassara H. (2001) The AGE-receptor in the pathogenesis of diabeteic complications. Diabetes Metab. Res. Rev. 17: 436-443.

18. Lee TC, Kimiagar M, Pintauro SJ, Chichester CO. (1981) Physiological and safety aspects of maillard browning of foods. Prog. Fd. Nutr. Sci. 5: 243-256.

19. O'Brien J. (1989) Nutritional and toxicological aspects of the maillard browning reaction in foods. Critical Reviews in food Science and Nutrition 28: 211-248.

20. Koschinsky T, He C, Mitsuhashi T, et al. (1997) Orally absorbed reactive glycation products (Glycotoxins): An environmental risk factor in diabetic nephropathy. Proc. Natl. Acad. Sci. USA 94: 6474-6479.

21. He C, Sabol J, Mitsuhashi T, Vlassara H. (1999) Dietary glycotoxins: inhibition of reactive products by aminoguanidine facilitates renal clearance and reduces tissue sequestration. Diabetes 48: 1308-1315.

22. Lin RY, Reis ED, Dore AT, et al. Lowering of dietary advanced glycation endoproducts (AGE) reduces neointimal formationafter arterial injury in genetically hypercholesterolemic mice. Atherosclerosis (in press).

23. Zheng F, He C, Cai W, et al. Prevention of diabetic nephropathy in mice by a diet low in glycoxidation products. Diab/Met. Res. Rev. (in press).

24. Hofmann S, Dong HJ, Zhu L, et al. Improved insulin sensitivity is associated with restricted intake of dietary glycoxidation products in th $\mathrm{db} / \mathrm{db}$ mouse. Diabetes (in press).

25. Vlassara H, Cai W, Crandall J, et al. Inflamatory markers are induced by dietary glycotoxins: a pathway for accelerated atherosclerosis in diabetes. (submitted).

26. Oya T, Hattori N, MizunoY, et al. (1999) Methylglyoxal modification of protein. J. Biol. Chem. 274: 18492-18502.

27. Horie K, Miyata T, Meada K, et al. (1997) Immunohistochemical colocalization of glycoxidation products and lipid peroxidation products in diabetic renal glomerular lessions. J. Clin. Invest. 100: 2995-3004.

28. Droge W, Schulzeosthoff K, Mihm S, et al. (1994) Functions of glutathione and glutathione disulfide in immunology and immunopathology. FASEB J 8: 1131-1138.

29. Knoepfel L, Steinkuhler C, Carri MT, Rotilio G. (1994) Role of zinc-coordination and of the glutathione redox couple in the redox susceptibility of human transcription factor Spl. Biochem. Biophys. Res. Commun. 201: 871-877.

30. Mitsuhashi T, Li YM, Fishbane S, Vlassara H. (1997) Depletion of reactive advanced glycation endoproducts from diabetic uremic sera using a lysozyme-linked matrix. J. Clin. Invest. 100: 847-854.

31. Sobal G, Menzel EJ, Sinzinger H. (2000) The effects of glycation/glycoxidation on the liberation of 8-epi-PGF P $_{2 \alpha}$ from low density lipoprotein during its in vitro oxidation. Prostaglandins, Leukotrienes and Essential Fatty Acids. 62: 217-224.

32. Bucala R, Makita Z, Vega G, et al. (1994) Modification of low density lipoprotein by advanced glycation end products contributes to the dyslipidemia of diabetes and renal insufficiency. Proc. Natl. Acad. Sci. USA 91: 9441-9445.
33. Founds HW, Sadeghi H. (1999) Monoclonal antibodies specific for advanced glycoxylation endproducts in biological samples. Patent Applicant: ALTEON, Inc., Ramsey, NJ, US5892000.

34. Mellinghoff AC, Reininger AJ, Wuerth JP, et al. (1997) Fromation of plasma advanced glycosylation end products (AGEs) has no influence on plasma viscosity. Diabetes Med. 14: 832-836.

35. Mitsuhashi T, Vlassara H, Founds HW, Li YM. (1997) Standardizing the immunological measurement of advanced glycation endproducts using normal human serum. J. Immunol. Med. 207: 79-88.

36. Li YM, Mitsuhashi T, Wojciechowicz D, et al. (1996) Molecular identity and cellular distribution of advanced glycation endproduct receptors: relationship of p60 to OST-48 and p90 to $80 \mathrm{~K}-\mathrm{H}$ membrane proteins. Proc. Natl. Acad. Sci. USA 93: 11047-11052.

37. Stitt AW, He C, Vlassara H. (1999) Characterization of the advanced glycation end-products receptor complex in human vascular endothelial cells. Biochem. Biophys. Res. Commun. 256: 549-556.

38. Shamsi FA, Partal A, Sady C, et al. (1998) Immunological evidence for methylglyoxal-derived modifications in vivo. J. Biol. Chem. 273: 6928-6936.

39. Che W, Asahi M, Takahashi M, et al. (1997) Selective induction of heparin-binding epidermal growth factor-like growth factor by methylglyoxal and 3-deoxyglucosone in rat aortic smooth muscle cells. J. Biol. Chem. 272: 18453- 18459.

40. Choudhary D, Chandra D, Kale RK. (1997) Influence of methylglyoxal on antioxidant enzymes and oxidative damage. Toxicol. Lett. 93: 141-152.

41. Odani $\mathrm{H}$, Shinzato $\mathrm{T}$, Usami J, et al. (1998) Imidazolium crosslinks derived from reaction of lysine with glyoxal and methylglyoxal are increased in serum proteins of uremic patients: evidence for increased oxidative stress in uremia. FEBS. Letters 427: 381-385.

42. Okado A, Kawasaki Y, Hasuike Y, et al. (1996) Induction of apoptotic cell death by methylglyoxal and 3-deoxyglucosone in macrophage-derived cell lines. Biochem biophys. Res. Commun. 225: 219-224.

43. Lyons TJ, Jenkins AJ. (1997) Lipoprotein glycation and its metabolic consequence. Cur. Opin. Lipidol. 8: 174-180.

44. Neeper M, Schmidt AM, Brett J, et al. Cloning and expression of a cell surface receptor for advanced glycosylation end products of proteins. J. Biol. Chem. 267: 14998-15004.

45. Vlassara H, Li YM, Imani F, et al. (1995) Identification of galectin-3 as a high-affinity binding protein for advanced glycation end products (AGE): a new member of AGE-receptor complex. Mol. Med. 1(6): 634-646.

46. Araki N, Higashi T, Mori T, et al. (1995) Macrophage scavenger receptor mediates the endocytic uptake and degradation of advanced glycation end products of the maillard reaction. Eur. J. Biochem. 230: 408-415.

47. Bierhaus A, Hofmann MA, Ziegler R, Nawroth PP. (1998) AGEs and their interaction with AGE-receptors in vascular disease and diabetes mellitus. I. The AGE concept. Cardiovascular Research 37: 586-600.

48. Giardino I, Fard AK, Hatchell DL, Brownlee M. (1998) Aminoguanidine inhibits reactive oxygen species formation, lipid peroxidation, and oxidant-induced apoptosis. Diabetes 47: 1114-1120.

49. Rattan, AK, Arad Y. (1998) Temporal and kinetic determinants of the inhibiter of LDL oxidation by $N$-acetylcysteine (NAC). Atherosclerosis 138: 319-327.

50. Perchellet EM, Maatta EA, Abney NL, Perchellet JP. (1987) Effects of diverse intracellular thiol delivery agents on gluthathione peroxidase activity, the ratio of reduced/ oxidized gluthathione, and ornithine decarboxylase induction in isolated mouse epidermal cells treated with 12 o-tetradecanoylphorbol-13-acetate. J. Cell Physiol. 131: 64-73. 